\title{
Habitat surrounding patch reefs influences the diet and nutrition of the western rock lobster
}

\author{
Lachlan D. MacArthur ${ }^{1,4, *}$, Donald L. Phillips ${ }^{2}$, Glenn A. Hyndes ${ }^{1}$, \\ Christine E. Hanson ${ }^{1,5}$, Mathew A. Vanderklift ${ }^{3}$ \\ ${ }^{1}$ Centre for Marine Ecosystems Research, School of Natural Sciences, Edith Cowan University, 270 Joondalup Dr, Joondalup, \\ Western Australia 6027, Australia \\ ${ }^{2}$ US Environmental Protection Agency, National Health and Environmental Effects Research Laboratory, 200 SW 35th St., \\ Corvallis, Oregon 97333, USA \\ ${ }^{3}$ CSIRO Marine and Atmospheric Research, Private Bag 5, Wembley, Western Australia 6913, Australia \\ ${ }^{4}$ Present address: Sinclair Knight Merz, 11th Floor Durack Centre, 263 Adelaide Tce, Perth, Western Australia 6000, Australia \\ ${ }^{5}$ Present address: School of Environmental Systems Engineering, The University of Western Australia, 35 Stirling Highway, \\ Crawley, Western Australia 6009, Australia
}

\begin{abstract}
This study investigated the influence of the spatial arrangement of habitat patches on the diet and nutrition of a common reef-associated generalist consumer, the western rock lobster Panulirus cygnus. Stable isotopes $\left({ }^{13} \mathrm{C} /{ }^{12} \mathrm{C}\right.$ and $\left.{ }^{15} \mathrm{~N} /{ }^{14} \mathrm{~N}\right)$ and gut contents were used to assess diet and nutrition of lobsters collected from 8 shallow patch-reef sites on the lower west coast of Australia in April and October 2005. A distance-based linear model indicated that the predominant benthic habitat surrounding a reef (seagrass or macroalgae/sand-dominated) was an important source of variation in diet and nutrition, explaining significant $(\mathrm{p}<0.01)$ variation in isotope signatures and gut contents of 52.7 and $7.0 \%$, respectively. Mobile invertebrates, sessile filter feeders, coralline algae and seagrass were consumed by lobsters from all sites, but sessile filter feeders (sponges and colonial ascidians) were consumed in significantly greater volumes $(p<0.05)$ at macroalgae/sand-dominated sites $(21.16 \pm 3.0 \%)$ than at seagrass-dominated sites $(\leq 6.1 \pm 1.08 \%)$. A modified mass balance mixing model (IsoSource), which factored in $\mathrm{C}: \mathrm{N}$ ratios of food sources and lobster-specific $\delta^{13} \mathrm{C}$ and $\delta^{15} \mathrm{~N}$ discrimination values, was used to determine the contribution of food sources to lobster nutrition. Articulated coralline red algae were an important source, especially from sites dominated by macroalgae and sand contributing $22-72 \%$ to nutrition. Bait potentially contributes up to $\sim 30 \%$ of lobster muscle nutrition and therefore may also play an important nutritional role for lobsters in areas where lobster potting occurs. Macroalgae, rather than seagrass, appears the most likely autochthonous energy source driving $P$. cygnus production in shallow coastal waters; however, seagrass plays an important role as habitat for lobster prey.
\end{abstract}

KEY WORDS: Stable isotope $\cdot$ Feeding $\cdot$ Landscape ecology $\cdot$ Seagrass $\cdot$ Mixing model $\cdot$ Panulirus cygnus

Resale or republication not permitted without written consent of the publisher

\section{INTRODUCTION}

The spatial arrangement of habitat patches in marine landscapes can alter processes that determine the abundance and size structure of organisms, such as rates of migration, predation and growth (e.g.
Posey \& Ambrose 1994, Irlandi \& Crawford 1997, Acosta 1999, Micheli \& Peterson 1999), and community composition within a habitat patch can be strongly influenced by the surrounding habitat (e.g. Tanner 2006, Grober-Dunsmore et al. 2007). It is also acknowledged that trophic linkages frequently cross 
habitat boundaries in marine environments (Polis et al. 1997, Rilov \& Schiel 2006, Valentine et al. 2007). Despite these findings, there have been few studies on the influence of spatial configuration of habitat patches on the diet of marine organisms, and thus the food-web structure in complex marine landscapes.

Patch reefs, both rocky and coral, are often interspersed with seagrass meadows, hard bottom and sand in shallow coastal waters. Many species of fish and crustaceans shelter into patch reefs and undertake foraging excursions in these surrounding habitats (e.g. Randall 1965, Jernakoff 1987, Parrish 1989, McAfee \& Morgan 1996, Cox et al. 1997, Meyer et al. 2000). Although the diet of many patch-reef consumers has been studied, there has been little focus on the diet variations of consumers among patch reefs with differing surrounding habitat. Spiny lobsters are ideal consumer organisms to investigate the influence of surrounding habitat on diet because they typically show strong homing movements around a single shelter (reef), but may forage over extensive distances into a number of surrounding habitat patches (e.g. Jernakoff 1987, Cox et al. 1997, MacArthur et al. 2008) and can influence adjacent community structure (Langlois et al. 2005).

The western rock lobster Panulirus cygnus is an abundant consumer in shallow $(<20 \mathrm{~m})$ coastal waters along the lower west coast of Australia (Joll \& Phillips 1984, Edgar 1990b), where it occupies high-relief limestone patch reefs that form a heterogeneous landscape with other habitats. P. cygnus forages in the dominant nearshore vegetated habitats along this coastline, i.e. meadows of seagrasses Posidonia spp. and Amphibolis spp., areas of bare sand and flat pavement reef dominated by macroalgae (Jernakoff 1987, Edgar 1990a, MacArthur et al. 2008), and, like other spiny lobsters, exhibits considerable spatial and temporal dietary variation (Joll \& Phillips 1984, Edgar 1990a). Previous studies indicate that P. cygnus consumes small mobile invertebrates, in particular gastropods and polychaetes, as well as both coralline and fleshy algae (Joll \& Phillips 1984, Edgar 1990a). Fragments of conspecifics have also been recorded, although these have been attributed to consumption of discarded shells of newly moulted lobster. Spatial dietary variation has been linked to changes in the abundance of prey between sites (Joll \& Phillips 1984, Edgar 1990a); however, the influence of habitat at a landscape scale has yet to be investigated. A common finding of previous studies is that relatively large volumes of epiphytic coralline algae are consumed by $P$. cygnus, although it has yet to be determined whether this food source contributes to lobster production.
Gut content analysis has traditionally been used to determine diet in lobsters (Joll \& Phillips 1984, Cox et al. 1997, Goni et al. 2001, Briones-Fourzan et al. 2003). This information can provide details on the type of prey consumed over a day or a few days, but one-off sampling may not highlight longer-term trends if temporal variation in diet is high. Stable isotopes ${ }^{13} \mathrm{C} /{ }^{12} \mathrm{C}$ and ${ }^{15} \mathrm{~N} /{ }^{14} \mathrm{~N}$, in contrast, serve as natural biomarkers that reflect the diet and trophic position of consumers (DeNiro \& Epstein 1978, Minagawa \& Wada 1984) over time spans of days to years (see Hobson 1999). The development of source partitioning mixing models has allowed the contribution of multiple food sources to a consumer's diet to be determined using ${ }^{13} \mathrm{C} /{ }^{12} \mathrm{C}$ and ${ }^{15} \mathrm{~N} /{ }^{14} \mathrm{~N}$ (e.g. Phillips \& Gregg 2003). Mixing models that incorporate concentration weighting of $\mathrm{C}$ and N (e.g. Koch \& Phillips 2002) increase the potential for stable isotopes to elucidate diet for omnivorous generalist consumers, such as lobsters, that forage on multiple food sources with different $\mathrm{C}$ and $\mathrm{N}$ ratios.

The primary objective of this study was to characterise the dietary variation in Panulirus cygnus from multiple patch reefs using gut content and stable isotope analysis and to test the hypothesis that the habitat surrounding patch reefs would explain a significant level of this variation. Habitat-related variation was compared with other potential or known sources of variation in lobster diets, i.e. among-site spatial variation, temporal variation, between-sex variation, carapace length variation and gut fullness variation. A mass-balance, concentration-weighted mixing model was used on stable isotope data to determine the nutritional importance of potential food sources and whether the importance of these groups differed with respect to habitat.

\section{MATERIALS AND METHODS}

\section{Study area}

This study was conducted within the Jurien Bay Marine Park $\left(30^{\circ} 17.3^{\prime} \mathrm{S}, 115^{\circ} 02.5^{\prime} \mathrm{E}\right)$ on the lower west coast of Australia (Fig. 1). Shallow waters $(<20 \mathrm{~m})$ in the region comprise a patchy landscape of limestone patch reefs interspersed with meadows of the seagrasses Amphibolis spp. and Posidonia spp., bare sand and limestone pavement (CALM 2005). Habitat patchiness occurs on a scale of 10 s to 100 s of metres in the area with seagrass more predominant in shallower, less-exposed waters. High-relief patch reefs are covered in red and brown macroalgae, 


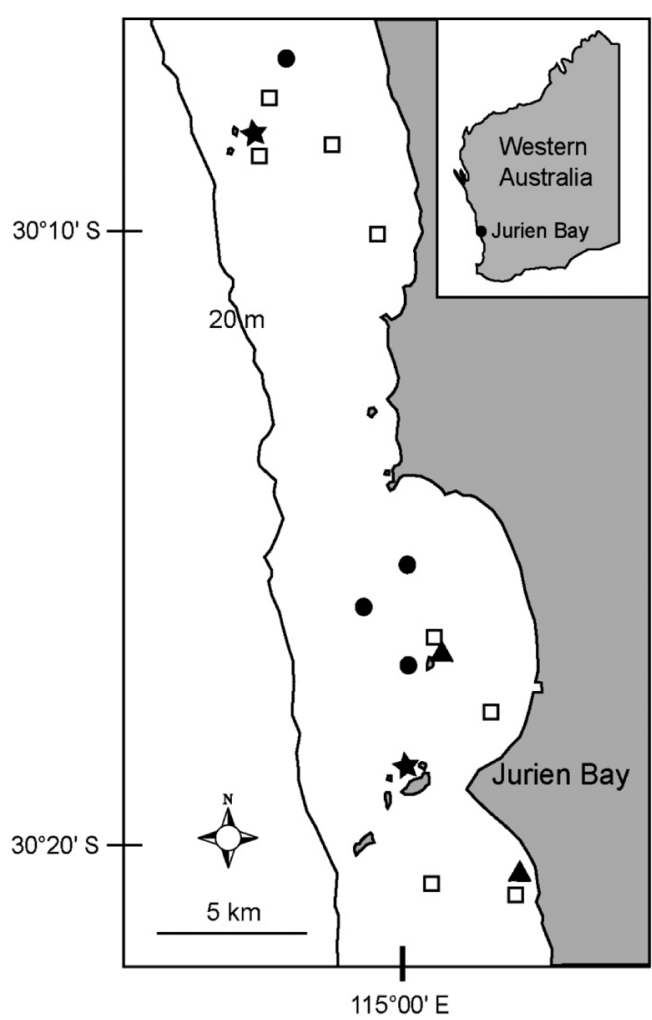

Fig. 1. Study area, showing the 8 sites from which lobsters Panulirus cygnus were collected in April and October 2005: Amphibolis spp. (A), Posidonia spp. (\), macroalgae/sand $(\boldsymbol{O})$ and the 8 sites from which food sources and primary producers were collected $(\square)$

sponges and ascidians, whereas flat pavement reefs are covered in predominantly red and brown macroalgae (L.D.M. pers. obs.) Using existing habitat maps (CALM 2005) and preliminary SCUBA surveys, we chose 8 patch-reef sites along a $30 \mathrm{~km}$ stretch of coastline for lobster collections: 2 sites surrounded mainly by Amphibolis spp. meadow and sand; 2 sites surrounded mainly by Posidonia spp. meadow and sand; 2 sites surrounded mainly by pavement and sand; and 2 sites surrounded mainly by pavement, Amphibolis spp. meadow and sand. To ground truth these a priori habitat categories, quantitative habitat surveys were conducted within a $100 \mathrm{~m}$ radius of patch reefs at each site. This revealed that sites classed as Amphibolis spp. and sand were not statistically different from those classed as pavement. These 2 habitat categories were, therefore, pooled into a single habitat category with 4 sites. This process yielded 3 habitat categories typified by the following habitats surrounding the patch reefs: Amphibolis spp. (2 sites), Posidonia spp. (2 sites) and macroalgae-dominated pavement and sand (macroalgae/sand; 4 sites).

\section{Collection of lobsters and potential food sources}

At each site, Panulirus cygnus were collected on 2 occasions (April and October 2005) by SCUBA divers using snares. Lobsters were collected $\sim 2 \mathrm{~h}$ after sunrise to minimize evacuation of gut contents because this species completes foraging excursions at approximately sunrise (Cobb 1981, Jernakoff 1987). Between 4 and 18 lobsters were collected from each site per occasion, covering the widest size range possible (36 to $98 \mathrm{~mm}$ carapace length [CL]; CL and sex were recorded for each lobster), and returned to a boat where they were euthanized in an ice slurry before their foreguts were removed and a sample of muscle tissue was taken from the abdomen. Foreguts were stored in $70 \%$ ethanol, whereas muscle samples were stored in chilled glass vials and frozen upon return to land.

A variety of potential food sources were collected from up to 8 sites within the study area (Fig. 1). Seagrass (Amphibolis griffithii and Posidonia sinuosa), fleshy red algae (Curdiea obesa, Hymenocladia dactyloides, Hypnea sp., Laurencia filiformis, Metamastophora flabellata, Polysiphonia sp. and Pterocladia lucida), articulated coralline red algae (Amphiroa anceps, Haliptilon roseum and Metagoniolithon stelliferum), green algae (Cladophora sp., Enteromorpha sp. and Ulva lactuca) and brown algae (Dictyopteris plagiogramma, Ecklonia radiata and Sargassum sp.) were collected to represent primary producers. Epiphytes were scraped off the seagrass leaves (periphyton). In addition, a number of potential animal prey of Panulirus cygnus were collected on reef or in seagrass meadows adjacent to reef. These included small gastropods (Cantharidus lepidus, Pyrene bidentata and Prothalotia lehmani), small crabs (Paguristes sulcatus and Pilumnus spp.), sea urchins (Heliocidaris erythrogramma), sponges (Thorectandra choanoides, Microcionid sp., Cymbastella sp., Chondropsis sp., Tedania sp., Chondrilla sp. and calcarean species), ascidians (Pyura sp., Herdmamia momus, Botryloides perspicuus and 2 unidentified species) and polychaetes (1 unidentified species).

\section{Gut content analysis}

Each lobster foregut was assigned a gut fullness score between zero and 10, determined by visual approximation (e.g. Edgar 1990a, Jernakoff et al. 1993), with zero indicating a completely empty gut and 10 indicating a completely distended gut. Guts 
assigned fullness scores of $<2$ were excluded from any subsequent analysis to ensure that no items with potentially longer retention rates dominated analyses, and to retain some consistency with previous diet studies on Panulirus cygnus (Joll \& Phillips 1984, Edgar 1990a, Jernakoff et al. 1993). Gut contents were washed onto a Petri dish with $70 \%$ ethanol, spread out evenly, and the dish was placed over gridded paper. Using a dissecting microscope, the percentage contribution to total gut volume was estimated for each unique food item by determining the proportion of total area that food item covered. Food items were later identified to as low a taxonomic group as possible.

\section{Stable isotope analysis}

For each site on each sampling occasion, muscle samples from up to 5 lobsters in 3 size categories (25-49, 50-74 and $\geq 75 \mathrm{~mm} \mathrm{CL}$ ) were randomly selected for stable isotope analysis. Samples were rinsed in deionised water and dried completely at $60^{\circ} \mathrm{C}$ before being ground to a fine powder in a ball mill. Similarly, 3 samples of plant, animal muscle, whole animal or multiple whole animals representing potential lobster food sources were analysed from up to 8 sites on each sampling occasion. Samples were cleaned, rinsed with de-ionised water, dried and ground as above. Samples which contained whole prey with calcium carbonate shells or exoskeletons and calcified algae samples were also treated with $1 \mathrm{M} \mathrm{HCl}$ to remove inorganic carbonate (Boutton 1991).

The $\delta^{13} \mathrm{C}$ and $\delta^{15} \mathrm{~N}$ for all samples (i.e. lobster and food sources) were determined using an ANCA-NT interfaced with a 20-20 isotope ratio mass spectrometer (Europa Scientific) using laboratory plant and fish standards. These standards had been previously calibrated against standard International Atomic Energy Agency reference materials with a precision of $<0.1 \%$. Results have been expressed as parts per mil (\%) in accordance with the Vienna PeeDee Belemnite or atmospheric $\mathrm{N}_{2}$ scales. In addition, \% C and $\% \mathrm{~N}$ of lobster and food source samples were determined at the same time as $\delta^{13} \mathrm{C}$ and $\delta^{15} \mathrm{~N}$.

\section{Distance-based linear model}

The predictor variables of habitat category (Amphibolis spp., Posidonia spp. and macroalgae/sand), site (8 sites), month (April or October), sex (M or F), CL (mm) and gut fullness (2 to 10) were used to evaluate variation in the gut content and stable isotope data. For this, a distance-based redundancy analysis (McArdle \& Anderson 2001) using the DistLM option within the PRIMER 6 \& PERMANOVA + $\beta 4$ software package was performed on the square-root transformed Bray-Curtis dissimilarity matrix of the percentage contribution to gut volume data (excluding sediment and unidentified material), and on the untransformed Euclidean distance matrix of the stable isotope values $\left(\delta^{13} \mathrm{C}\right.$ and $\left.\delta^{15} \mathrm{~N}\right)$ from lobster muscle samples. The proportion of total variation explained by each of these predictor variables and their significance levels were used to compare their relationship with lobster gut contents and stable isotopes (marginal tests). Conditional tests were also performed, whereby predictor variables were selected and added to the model using the 'forward' option and Akaike's information criterion (AIC; Akaike 1974) within DistLM. The cumulative proportion of total variation explained by each predictor variable and significance level has been presented. Post hoc PERMANOVA pairwise comparisons (using a multivariate version of the $t$-statistic) were made between lobsters collected from different habitats (i.e. Amphibolis spp., Posidonia spp. and macroalgae/sand) within the PRIMER 6 \& PERMANOVA + $\beta 4$ software package.

\section{Mixing model analysis}

Using results from gut content analysis from this and previous studies (i.e. Joll \& Phillips 1984, Edgar 1990a) as a guide, 9 natural food sources that were considered important to Panulirus cygnus diet were included in a mass-balance mixing model (see Table 1 and above for food sources and species representing these sources). In addition to these natural food sources, bait was included in the analysis for lobsters collected from the macroalgae/sand habitat (Table 1). The bait isotopic signature was taken from Waddington et al. (2008) and represents the average 2 commonly used baits: pilchards Sardinops sagax and mackerel Scomber spp. Sites that comprised mainly macroalgae/sand habitat were subjected to fishing effort by commercial and recreational fishers using baited pots during the fishing season over the course of this study (mid-November until the end of June, L.D.M. pers. obs.). In contrast, 3 of the 4 seagrass-habitat sites were located in sanctuary zones, protected from fishing, and the remaining site was never observed to be fished over 
Table 1. Details of food sources, food groups, $\delta^{13} \mathrm{C}$ and $\delta^{15} \mathrm{~N}$ and digestible $\mathrm{C}$ and $\mathrm{N}$ concentrations used in the mass-balance mixing model. Digestible $\mathrm{C}, \mathrm{N}$ and $\mathrm{C}: \mathrm{N}$ for the coralline algae and seagrass food sources were derived from Corallina officinalis and Posidonia australis, respectively. See 'Materials and methods' for calculations

\begin{tabular}{|c|c|c|c|c|c|c|}
\hline Food source & Food group & $\begin{array}{l}\delta^{13} \mathrm{C} \\
(\% \circ)\end{array}$ & $\begin{array}{l}\delta^{15} \mathrm{~N} \\
(\%)\end{array}$ & $\mathrm{C}(\%)$ & $\begin{array}{c}\text { Digestible } \\
\text { N (\%) }\end{array}$ & $C: N$ \\
\hline Crabs & Animal, mobile invertebrate & -18.31 & 6.89 & 31.57 & 8.24 & 3.8 \\
\hline Lobsters & Animal, mobile invertebrate & -16.83 & 8.35 & 44.75 & 13.5 & 3.3 \\
\hline Sea urchins & Animal, mobile invertebrate & -16.97 & 6.57 & 36.72 & 10.68 & 3.4 \\
\hline Gastropods & Animal, mobile invertebrate & -18.21 & 4.89 & 41.86 & 10.15 & 4.1 \\
\hline Polychaetes & Animal, mobile invertebrate & -19.82 & 5.62 & 48.04 & 11.31 & 4.0 \\
\hline Sponges & Animal, sessile filter feeder & -17.32 & 5.58 & 19.72 & 3.60 & 5.5 \\
\hline Ascidians & Animal, sessile filter feeder & -20.71 & 5.81 & 28.11 & 3.69 & 7.6 \\
\hline Bait & Animal & -20.75 & 8.61 & 42.5 & 11.2 & 3.8 \\
\hline Coralline algae & Coralline algae & -24.45 & 4.16 & 48.27 & 6.31 & 7.7 \\
\hline Seagrass & Seagrass & -10.82 & 3.87 & 50.03 & 1.81 & 27.6 \\
\hline
\end{tabular}

the study period. Because lobsters below legal size limit (76 or $77 \mathrm{~mm}$ CL, depending upon the time of year) can leave pots through escape gaps or are returned to the water by fishers after feeding on bait, a wide size range of lobsters can potentially feed upon discarded bait. This food source was therefore considered potentially important for lobsters during the fishing season. Data from the diet of lobsters in both shallow $(<5 \mathrm{~m})$ and deeper $(35$ to $60 \mathrm{~m})$ water suggest that bait may be seasonally important (Edgar 1990a, Waddington et al. 2008)

Because 10 potential food sources were chosen, yet only 2 parameters $\left(\delta^{13} \mathrm{C}\right.$ and $\left.\delta^{15} \mathrm{~N}\right)$ were measured, there was no unique mixing model solution for diet composition (see Phillips \& Gregg 2003). A sourcepartitioning model (IsoSource) described by Phillips \& Gregg (2003) was therefore used to estimate likely ranges of food sources. This model identifies multiple solutions by examining all possible combinations of biomass contributions of sources between 0 and $100 \%$ in small increments. Combinations that result in the observed consumer isotopic $\delta^{13} \mathrm{C}$ and $\delta^{15} \mathrm{~N}$ (within some small tolerance) are considered to be isotopically feasible solutions. Distribution frequencies of food sources from feasible solutions were then used to indicate the range of potential food source combinations. Because Panulirus cygnus is omnivorous, consuming plants and animals that typically differ in $\mathrm{C}$ and $\mathrm{N}$ concentrations and C:N, the standard IsoSource model was modified (see Newsome et al. 2004) to incorporate concentration weighting principles used in the IsoConc 3-source mixing model (see Koch \& Phillips 2002). The model was run using $2 \%$ increments of source contributions and a tolerance of $0.1 \%$.

Because stable isotope analysis indicates the composition of the diet that is actually assimilated, it is important to account for effects of differential digestibility on the $\mathrm{C}$ and $\mathrm{N}$ concentrations of digested material, rather than just using concentrations in ingested material (Koch \& Phillips 2002). The procedures outlined by Koch \& Phillips (2002) and Newsome et al. (2004) were used to adjust digested C and $\mathrm{N}$ content based on the macromolecular composition of each food source and their likely digestibility. All proteins, lipids and non-structural carbohydrates in plants and animals were assumed to be totally digestible by lobsters, and because animal sources mainly comprise these constituents, no correction was made to $\mathrm{C}$ and $\mathrm{N}$ concentrations for these sources. Coralline algae and seagrass, however, contain structural carbohydrates such as cellulose, hemicellulose and lignin, which are indigestible to many organisms (Cebrian \& Duarte 1998, McDermid et al. 2005). For the articulated coralline red algae, a published composition of the con-familial Corallina officinalis from Marsham et al. (2007) was used to estimate macromolecular composition. For seagrass, the macromolecular composition of Posidonia australis from Torbatinejad et al. (2007) and Nichols et al. (1982) was used. It was assumed that hemicellulose/ cellulose had $50 \%$ digestibility based on evidence that decapods digested fibre with efficiencies ranging from low (37 to $57 \%$, Jones \& De Silva 1997) to high (80\%, Gonzalez-Pena et al. 2002; 95\%, Catacutan et al. 2003), and because spiny lobster guts contain the cellulose-digesting enzyme, cellulase (e.g. Jasus edwardsii; Johnston 2003). Lignin, however, was assumed to have $0 \%$ digestibility for lobsters. Proteins, lipids and non-structural carbohydrates in seagrass and coralline algae were assumed to have $100 \%$ digestibility. Further, it was assumed that carbon comprised 52, 75 and $45 \%$ of proteins, 
lipids and carbohydrates, respectively, whereas nitrogen comprised $16 \%$ protein (Robbins 1993, cited in Newsome et al. 2004). The total amount (in g) of digested $\mathrm{C}$ and $\mathrm{N}$ per $100 \mathrm{~g}$ ingested was determined using the macromolecular composition, digestibility factors and $\mathrm{C}$ and $\mathrm{N}$ compositions of each macromolecular type. These $\mathrm{C}$ and $\mathrm{N}$ amounts were then divided by the total amount of matter digested to obtain digestible $\mathrm{C}$ and $\mathrm{N}$ concentrations, and then digestible $\mathrm{C}: \mathrm{N}$ ratios for animals and plants (Table 1).

To account for physiological processes that alter $\delta^{13} \mathrm{C}$ and $\delta^{15} \mathrm{~N}$ between the diet and muscle tissue of lobsters, i.e. consumer-diet discrimination (DeNiro \& Epstein 1978, Minagawa \& Wada 1984), values of 3.20 and $2.57 \%$, determined for Panulirus cygnus muscle tissue by Waddington \& MacArthur (2008), were added to $\delta^{13} \mathrm{C}$ and $\delta^{15} \mathrm{~N}$ values, respectively. These values were derived by averaging discrimination values determined for lobsters fed mussel, pilchard, coralline algae and mixed mussel and coralline algae diets (Waddington \& MacArthur 2008). The discrimination value of $\delta^{13} \mathrm{C}$ we used differs from the range determined by DeNiro \& Epstein (1978) (0 to $1 \%$ ), which is commonly used in studies where an exact consumer-diet discrimination factor is not known.

After mixing model solutions for each of the food sources were determined, food sources were aggregated to allow a posteriori groups to be compared, and to constrain the range of feasible solutions (see Phillips et al. 2005). (1) Individual animal sources grouped into 'mobile invertebrates' and 'sessile filter feeders' (Table 1), together with 'bait', 'coralline algae' and 'seagrass', formed the food sources. (2) All animal food sources combined into an 'animal' group (Table 1) were included with 'coralline algae' and 'seagrass' for the food sources.

Due to synergies between research projects in the region, the food sources used in the mixing model were collected from a number of different sites that often did not match the lobster collection sites. This was potentially a confounding factor in the mixing model analysis. However, it was assumed that there was minimal chance of potential differences in prey and lobster habitat confounding the results of the IsoSource mixing model because: (1) in the absence of site-matched isotope signatures between lobsters and prey, food sources were averaged over a number of sites covering a wide area to reduce bias towards a particular area or site; (2) food sources were collected from the same types of habitat patches as those at the lobster collection sites; and (3) the lobsters forage over distances of 100 s of metres (MacArthur et al.
2008), which would average out any variability in stable isotope in food sources (NB such variability was often greatest over 100 s of metres; G.A.H. unpubl. data).

\section{RESULTS}

\section{Gut content analysis}

There was no statistical difference in the proportion of animal prey (ANOVA, p = 0.535, $F=0.657$, df $=2,13$ ) or plant material (ANOVA, $\mathrm{p}=0.3756, F=$ 1.058, df $=2,13$ ) consumed by lobsters among the 3 habitat categories. Animal prey comprised $45.4 \pm$ $8.62,33.9 \pm 10.15$ and $49.3 \pm 8.68 \%$ of total gut volume for lobsters collected from Amphibolis spp., Posidonia spp. and macroalgae and sand dominated sites, respectively (Table 2). Plant material comprised $52.2 \pm 5.26,59.4 \pm 10.14$ and $41.8 \pm 8.34 \%$ of total gut volume for lobsters collected from sites dominated by Amphibolis spp., Posidonia spp., or macroalgae/ sand, respectively (Table 2).

For lobsters collected from sites dominated by Amphibolis spp., gastropods were the most important animal group consumed, in terms of volume, contributing on average $16.06 \pm 6.059 \%$ to total gut volume (Table 2). The most important gastropod families were Trochidae $(4.4 \pm 1.69 \%)$ and Columbellidae $(4.6 \pm 0.98 \%)$. Gastropods were consumed in smaller quantities by lobsters collected from sites dominated by macroalgae/sand $(3.1 \pm 1.12 \%$; $t$-test, $\mathrm{p}<0.05, t=$ 2.95 , df $=10$ ). Crustaceans were relatively important contributors to gut volume for lobsters collected from sites dominated by Amphibolis spp. (14.1 $\pm 4.96 \%)$, Posidonia spp. $(4.8 \pm 1.68 \%)$ or macroalgae/sand $(15.7 \pm 6.37 \%)$. However, there was no significant difference between these habitat categories (ANOVA, $\mathrm{p}=0.461, F=0.824, \mathrm{df}=2,13)$. Pilumnid crabs were the most important crustacean taxa at sites dominated by Amphibolis spp. $(5.2 \pm 2.64 \%)$, whereas conspecifics (fragments) were the most important crustacean taxa at sites dominated by Posidonia spp. (1.9 $\pm 1.88 \%$ ) or macroalgae/sand $(8.7 \pm 5.87 \%$; Table 2$)$.

All other invertebrate animal taxa (with the exception of sponges and ascidians) contributed $<4 \%$ to total gut volume regardless of habitat. This list of taxa comprised polyplacophorans (chitons), bivalves, echinoderms (Heliocidaris erythrogramma), polychaetes, sipunculans, hydrozoans and bryozoans (Table 2).

There was considerable variation in the proportion of sponges and didemnid ascidians consumed by lob- 
sters from different habitats, with lobsters from macroalgae/sand-dominated sites consuming a greater volume $(21.162 \pm 3.0044 \%)$ than lobsters from sites dominated by Amphibolis spp. (6.1 \pm $1.08 \%$; $t$-test, $\mathrm{p}<0.01, t=4.03, \mathrm{df}=10$ ) or Posidonia spp. $(4.9 \pm 2.88 \% ; t$-test, $\mathrm{p}<0.05, t=4.03, \mathrm{df}=10)$. It was not possible to separate sponges from didemnid ascidians or to identify sponges to a lower taxonomic level.

Articulated coralline red algae formed one of the most important contributors to gut volume for lobsters collected from all habitats, comprising approximately one-third by volume $(27.1 \pm 5.93$ to $34.0 \pm 5.78 \%)$ of all items consumed (Table 2). There was no significant variation in the proportions consumed among habitat categories (ANOVA, $\mathrm{p}=0.662, F=$ 0.426 , $\mathrm{df}=2,13)$; however, the species of algae consumed tended to differ. Lobsters from the macroalgae/sanddominated habitat consumed mainly Amphiroa spp. whereas lobsters from habitats dominated by Amphibolis spp. and Posidonia spp. consumed mainly epiphytic Haliptilon roseum and Metagoniolithon stelliferum.

Seagrass comprised a relatively large proportion of the gut volume of lobsters from macroalgae and sand $(11.0 \pm 5.96 \%)$, Amphibolis spp. (13.1 $\pm 1.43 \%$ ) and Posidonia spp. (18.4 \pm $4.38 \%$ ) habitats. These contributions were not significantly different $($ ANOVA $, \mathrm{p}=0.664, F=0.423, \mathrm{df}=$ $2,13)$.

\section{Stable isotope values of lobsters, food sources and primary producers}

There was a clear separation of lobsters, invertebrate prey and primary producers along the $\delta^{15} \mathrm{~N}$ axis of the stable isotope plot (Fig. 2). Lobster $\delta^{15} \mathrm{~N}$ averaged over the 3 habitats had a significantly higher mean $\delta^{15} \mathrm{~N}$ value than invertebrate prey $(8.3 \pm 0.3$ vs. $5.9 \pm 0.3 \%$; $t$-test, $\mathrm{p}<0.01, t=5.29$, $\mathrm{df}=7$ ). Similarly, invertebrate prey had higher mean $\delta^{15} \mathrm{~N}$ values than primary producers $(5.9 \pm 0.3$ vs. $3.98 \pm$
$0.075 \%$; $t$-test, $\mathrm{p}<0.001, t=6.38, \mathrm{df}=10$ ). Bait $(8.61 \%$ ) occupied a similar position to lobsters along the $\delta^{15} \mathrm{~N}$ axis

The mean $\delta^{13} \mathrm{C}$ values of primary producers occupied a broad range $(-24.45 \pm 0.23$ to $-10.82 \pm 0.32 \%)$ along the $\delta^{13} \mathrm{C}$ axis (Fig. 2). There was a clear separa-

Table 2. Contribution (mean percent $\pm 1 \mathrm{SE}$ ) of prey taxa to total gut volume of 138 Panulirus cygnus collected from 4 sites dominated by macroalgae and sand, 2 sites dominated by Posidonia spp. and 2 sites dominated by Amphibolis spp. during April and October 2005. Mean values are averaged over sites and the 2 sampling occasions

\begin{tabular}{|c|c|c|c|}
\hline \multirow[t]{2}{*}{ Prey items } & \multicolumn{3}{|c|}{ Percent contribution to gut volume } \\
\hline & $\begin{array}{l}\text { Macroalgae/ } \\
\text { sand }\end{array}$ & $\begin{array}{l}\text { Posidonia } \\
\text { spp. }\end{array}$ & $\begin{array}{l}\text { Amphibolis } \\
\text { spp. }\end{array}$ \\
\hline ANIMALS & $49.3 \pm 8.68$ & $33.9 \pm 10.15$ & $45.4 \pm 8.62$ \\
\hline Gastropods & $3.1 \pm 1.12$ & $7.8 \pm 5.86$ & $16.06 \pm 6.059$ \\
\hline Phasianellids & $0.25 \pm 0.152$ & $0.8 \pm 0.76$ & $1.1 \pm 0.46$ \\
\hline Cerithiids & $0.09 \pm 0.044$ & $0 \pm 0$ & $0.6 \pm 0.42$ \\
\hline Trochids & $1.3 \pm 0.77$ & $5.9 \pm 5.60$ & $4.4 \pm 1.69$ \\
\hline Columbellids & $0.46 \pm 0.196$ & $0.7 \pm 0.59$ & $4.6 \pm 0.98$ \\
\hline Volutids & $0.22 \pm 0.149$ & $0 \pm 0$ & $0.6 \pm 0.37$ \\
\hline Epitoniids & $0 \pm 0$ & $0.18 \pm 0.182$ & $2.5 \pm 2.15$ \\
\hline Fissurellids & $0.66 \pm 0.276$ & $0 \pm 0$ & $0.4 \pm 0.42$ \\
\hline Unidentified gastropods & $0.12 \pm 0.084$ & $0.12 \pm 0.125$ & $1.8 \pm 1.15$ \\
\hline Polyplacophorans & $0.08 \pm 0.078$ & $0.5 \pm 0.35$ & $1.4 \pm 0.89$ \\
\hline Bivalves & $1.8 \pm 0.48$ & $1.2 \pm 0.72$ & $2.8 \pm 0.72$ \\
\hline Mytilids & $0.9 \pm 0.44$ & $0.6 \pm 0.62$ & $1.3 \pm 0.52$ \\
\hline Unidentified bivalves & $0.91 \pm 0.280$ & $0.6 \pm 0.62$ & $1.5 \pm 0.42$ \\
\hline Crustaceans & $15.7 \pm 6.37$ & $4.8 \pm 1.68$ & $14.1 \pm 4.96$ \\
\hline Pilumnid crabs & $3.1 \pm 1.14$ & $0.25 \pm 0.250$ & $5.2 \pm 2.64$ \\
\hline Diogenid crabs & $0.043 \pm 0.0299$ & $0.15 \pm 0.119$ & $0.8 \pm 0.51$ \\
\hline Halicarcinus spp. & $0.5 \pm 0.54$ & $0 \pm 0$ & $0.07 \pm 0.071$ \\
\hline Panulirus cygnus & $8.7 \pm 5.87$ & $1.9 \pm 1.88$ & $0.9 \pm 0.89$ \\
\hline Unidentified crustaceans & $0.29 \pm 0.190$ & $2.1 \pm 1.81$ & $2.5 \pm 1.30$ \\
\hline Echinoderms & $3.1 \pm 2.45$ & $1.1 \pm 1.14$ & $1.1 \pm 0.82$ \\
\hline Heliocidaris erythrogramma & $3.1 \pm 2.45$ & $1.1 \pm 1.14$ & $1.1 \pm 0.82$ \\
\hline Polychaetes & $1.6 \pm 0.92$ & $1.1 \pm 1.06$ & $1.6 \pm 1.55$ \\
\hline Nereids & $0.07 \pm 0.069$ & $0.25 \pm 0.250$ & $0.22 \pm 0.220$ \\
\hline Other polychaetes & $1.5 \pm 0.91$ & $0.8 \pm 0.81$ & $1.4 \pm 1.33$ \\
\hline Sipunculans & $0.18 \pm 0.138$ & $2.1 \pm 1.06$ & $0.30 \pm 0.208$ \\
\hline Hydrozoans & $0.14 \pm 0.082$ & $0 \pm 0$ & $0 \pm 0$ \\
\hline Bryozoans & $0 \pm 0$ & $0.05 \pm 0.050$ & $1.2 \pm 1.13$ \\
\hline Ascidians and sponges & $23.5 \pm 2.84$ & $8.91 \pm 6.103$ & $6.8 \pm 0.85$ \\
\hline Pyurid ascidians & $2.4 \pm 1.22$ & $4.0 \pm 3.64$ & $0.7 \pm 0.51$ \\
\hline $\begin{array}{l}\text { Sponge and didemnid } \\
\text { ascidians }\end{array}$ & $21.162 \pm 3.0044$ & $4.9 \pm 2.88$ & $6.1 \pm 1.08$ \\
\hline Teleosts & $0.014 \pm 0.0142$ & $6.25 \pm 6.250$ & $0 \pm 0$ \\
\hline PLANTS & $41.8 \pm 8.34$ & $59.4 \pm 10.14$ & $52.2 \pm 5.26$ \\
\hline Red algae & $29.8 \pm 7.40$ & $37.5 \pm 7.74$ & $38.7 \pm 4.99$ \\
\hline Articulated corallines & $27.1 \pm 5.93$ & $33.81 \pm 6.034$ & $34.0 \pm 5.78$ \\
\hline Filamentous red algae & $2.0 \pm 2.02$ & $3.7 \pm 2.07$ & $4.3 \pm 1.33$ \\
\hline Foliose red algae & $0.7 \pm 0.46$ & $0 \pm 0$ & $0.39 \pm 0.229$ \\
\hline Brown algae & $0.3 \pm 0.31$ & $2.9 \pm 2.26$ & $0.40 \pm 0.235$ \\
\hline Unidentified algae & $0.71 \pm 0.213$ & $0.6 \pm 0.65$ & $0.055 \pm 0.0554$ \\
\hline Seagrass & $11.0 \pm 5.96$ & $18.4 \pm 4.38$ & $13.1 \pm 1.43$ \\
\hline UNIDENTIFIED MATERIAL & L $\quad 6.8 \pm 2.22$ & $4.5 \pm 1.12$ & $2.0 \pm 0.89$ \\
\hline SEDIMENT & $2.1 \pm 0.87$ & $2.2 \pm 1.91$ & $0.41 \pm 0.123$ \\
\hline
\end{tabular}




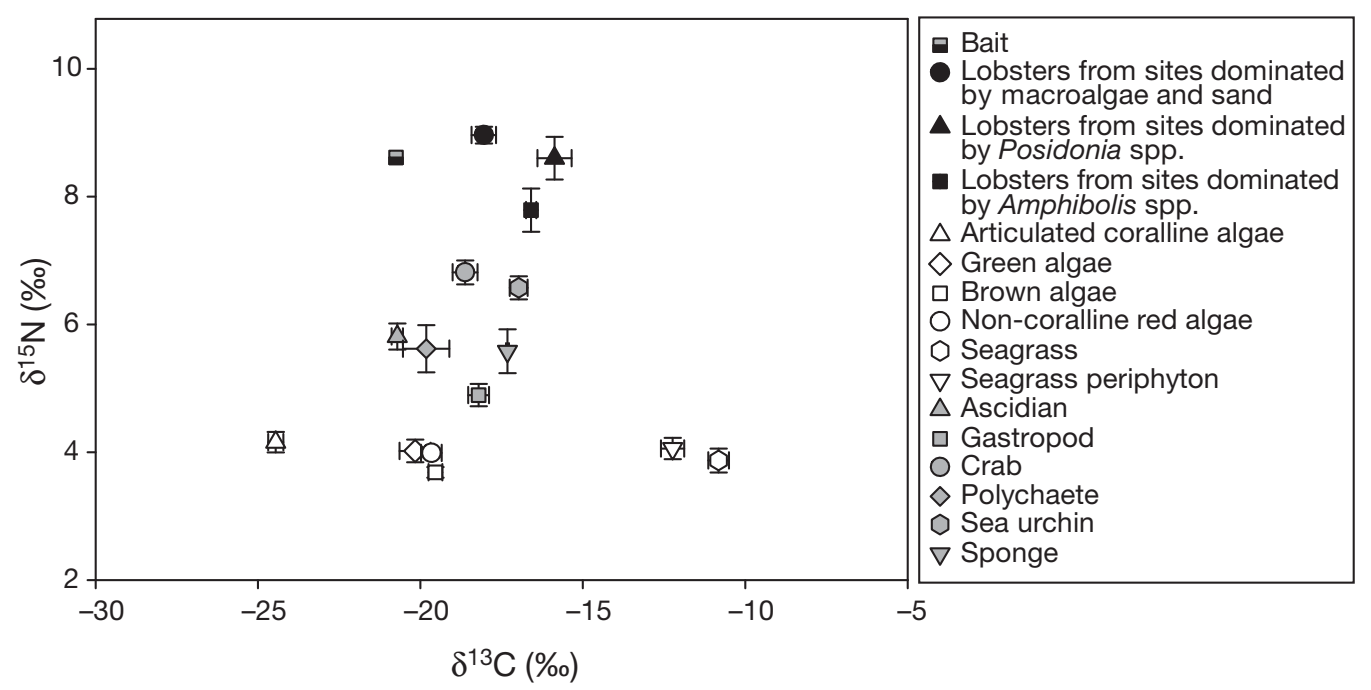

Fig. 2. $\delta^{13} \mathrm{C}$ and $\delta^{15} \mathrm{~N}$ values (mean $\pm 1 \mathrm{SE}$ ) of Panulirus cygnus from sites dominated by Amphibolis spp., Posidonia spp., and macroalgae and sand, as well as values of potential food sources and primary producers

tion of some primary producer groups, with articulated coralline red algae $(24.45 \pm 0.23 \%)$, non-coralline red, brown and green macroalgae ( $-20.16 \pm 0.48$ to -19.54 $\pm 0.21 \%)$ and periphyton and seagrass $(-12.17 \pm 0.36$ to $-10.82 \pm 0.32 \%$ ) forming distinct groups. The mean $\delta^{13} \mathrm{C}$ value of lobsters averaged over the 3 habitats was not significantly different to that of invertebrate prey $(-16.83 \pm 0.63$ vs. $-18.6 \pm 0.54 ; t$-test, $\mathrm{p}=0.1043$, $t=1.87, \mathrm{df}=7$ ) whereas the mean $\delta^{13} \mathrm{C}$ value of invertebrate prey was not significantly different to that of non-coralline macroalgae $(-18.6 \pm 0.54$ vs. $-19.8 \pm$ 0.19 ; $t$-test $, \mathrm{p}=0.2179, t=1.35, \mathrm{df}=7$ ).

\section{Variables explaining gut content and stable isotope variation}

Distance-based redundancy analyses revealed that habitat (i.e. macroalgae/sand, Amphibolis spp. or Posidonia spp.) explained 7.0 and $52.7 \%$ of the total variation in lobster gut contents and lobster muscle stable isotope values, respectively (Table 3 ). Site explained the same amount of total variation in gut contents as habitat, but the proportion of total variation explained by gut fullness and CL was considerably lower ( $\leq 1.6$ vs. $7.0 \%$ ). Neither sex nor month explained a significant proportion of the total variation in gut contents between lobsters (Table 2). Habitat explained a much higher proportion of total variation in stable isotopes values than site (52.7 vs. $18.8 \%$; Table 3 ). CL, sex and month did not explain a significant proportion of the total variation in stable isotope values between lobsters.

A combination of habitat, site, gut fullness and CL explained $16.9 \%$ of total variation between lobster gut contents (Table 3). Of this $16.9 \%$, habitat and site each explained $7.0 \%$, whereas gut fullness and CL explained a further 1.6 and $1.3 \%$, respectively (Table 3). A combination of habitat and site variables explained $67.1 \%$ of total variation in stable isotopes between lobsters, of which habitat explained $52.7 \%$ and site explained the remainder (Table 3).

Table 3. Distance-based linear model to explain variation in Panulirus cygnus gut contents and muscle stable isotopes $\left(\delta^{13} \mathrm{C}\right.$ and $\left.\delta^{15} \mathrm{~N}\right)$. Table shows marginal statistics and \% of total variation explained for each variable tested individually; and cumulative statistics and cumulative \% of total variation of combined variables added sequentially to the model using Akaike's information criterion. Significant p-values $(<0.05)$ are in bold

\begin{tabular}{|c|c|c|c|c|c|c|}
\hline \multirow{2}{*}{$\begin{array}{l}\text { Predictor } \\
\text { variable }\end{array}$} & \multicolumn{3}{|c|}{ - Gut contents- } & \multicolumn{3}{|c|}{-Stable isotopes - } \\
\hline & $F$ & $\mathrm{p}$ & \% Var. & $F$ & $\mathrm{p}$ & \% Var. \\
\hline \multicolumn{7}{|l|}{ Marginal statistics } \\
\hline Habitat & 4.96 & 0.001 & 7.0 & 75.81 & 0.001 & 52.7 \\
\hline Site & 2.00 & 0.001 & 7.0 & 6.17 & 0.001 & 18.8 \\
\hline Gut fullness & 2.23 & 0.02 & 1.6 & & & \\
\hline Carapace length & 1.97 & 0.04 & 1.4 & 0.69 & 0.473 & 0.5 \\
\hline Sex & 1.60 & 0.101 & 1.2 & 1.68 & 0.170 & 1.2 \\
\hline Month & 1.28 & 0.232 & 0.9 & 0.23 & 0.741 & 1.7 \\
\hline \multicolumn{7}{|l|}{ Cumulative statistics } \\
\hline Habitat & 4.96 & 0.001 & 7.0 & 75.8 & 0.001 & 52.7 \\
\hline+ Site & 2.09 & 0.002 & 14.0 & 11.5 & 0.001 & 67.1 \\
\hline + Gut fullness & 2.41 & 0.015 & 15.6 & & & \\
\hline + Carapace length & 2.05 & 0.030 & 16.9 & & & \\
\hline
\end{tabular}


Pairwise tests revealed that the significant habitatrelated differences in the gut contents and stable isotope values of lobsters were due to significant differences between seagrass habitats (i.e. Amphibolis spp. and Posidonia spp.) and macroalgae/sand habitat (Table 4). There were, however, no significant differences in the gut contents or stable isotopes between lobsters collected from sites dominated by Amphibolis spp. and those dominated by Posidonia spp. (Table 4). The 2 seagrass habitats have therefore been pooled for further analyses.

\section{Mixing model analysis}

Mixing model analysis indicated that all food sources selected in the model could have potentially contributed to the nutrition of lobsters from seagrassand macroalgae/sand-dominated sites as they all had feasible solutions $>0 \%$ (Fig. 3a). Of the animal food sources, no single source was absolutely necessary for the model to balance because they all also took a minimum (1st percentile) value of $0 \%$. The model indicated potentially higher contributions of sea urchins, gastropods, polychaetes and sponges to the nutrition of lobsters from seagrass-dominated sites and a potentially higher contribution of lobsters (cannibalism) to the nutrition of lobsters from macroalgae/sand-dominated sites. Bait provided the highest median contribution of any animal food source (18\%) to the model for lobsters from macroalgae/sanddominated sites. The mixing model indicated a major difference in the likely contribution of coralline algae to the nutrition of lobsters from seagrass- and macroalgae/sand-dominated sites. The mixing model indicated that coralline algae contribute a minimum of $22 \%$ to diet of lobsters from macroalgae/sand sites compared with a minimum of $0 \%$ at seagrass sites. Further, the maximum (99th percentile) feasible con-

Table 4. PERMANOVA pairwise comparisons of Panulirus cygnus gut contents and muscle stable isotopes $\left(\delta^{13} \mathrm{C}\right.$ and $\left.\delta^{15} \mathrm{~N}\right)$ between habitats. Significant p-values $(<0.05)$ are in bold

\begin{tabular}{|lcccc|}
\hline \multirow{2}{*}{ Predictor variable } & \multicolumn{2}{c}{ Gut contents } & \multicolumn{2}{c|}{ Stable isotopes } \\
& $t$ & $\mathrm{p}$ & $t$ & $\mathrm{p}$ \\
\hline $\begin{array}{l}\text { Amphibolis spp. vs. } \\
\text { macroalgae/sand }\end{array}$ & 1.68 & $\mathbf{0 . 0 1 0}$ & 3.61 & $\mathbf{0 . 0 1 2}$ \\
$\begin{array}{c}\text { Amphibolis spp. vs. } \\
\text { Posidonia spp. }\end{array}$ & 0.79 & 0.770 & 1.33 & 0.291 \\
$\begin{array}{l}\text { Macroalgae/sand vs. } \\
\text { Posidonia spp. }\end{array}$ & 1.75 & $\mathbf{0 . 0 0 6}$ & 3.23 & $\mathbf{0 . 0 1 8}$ \\
\hline
\end{tabular}

tribution of coralline algae was higher for lobsters from macroalgae/sand-dominated sites (72\%) compared with seagrass-dominated sites $(42 \%)$. For the individual food sources, mean contributions to gut volume were within the feasible ranges indicated by
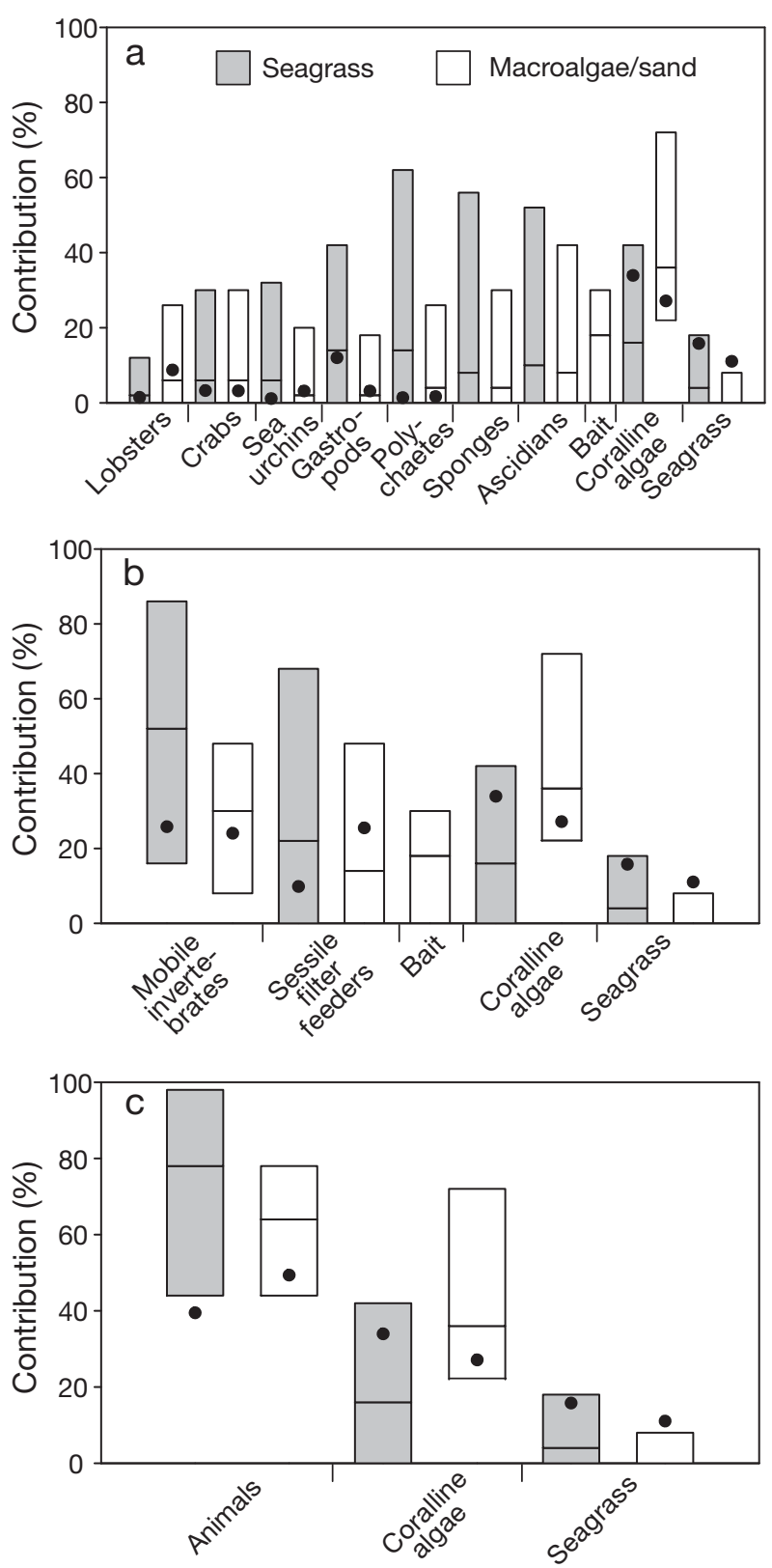

Fig. 3. Feasible contributions of food sources to the nutrition of Panulirus cygnus collected from seagrass- and macroalgae/sand-dominated sites. Mass balance mixing model results showing median values (bar bisect lines) and 1st and 99th percentiles (bar edges). (a) Results for individual food sources; $(\mathrm{b}, \mathrm{c})$ results from 2 different a posteriori groupings. Overlayed points show the mean contribution of these sources to total gut volume from the gut content analysis 
the mixing model, with the exception of seagrass for lobsters from macroalgae/sand-dominated sites (Fig. 3a). However, some of the trends between habitats were not mirrored, the most notable example being the similar consumption of coralline algae between habitats, as shown by gut content analysis, contrasting the greater contribution of coralline algae to the nutrition of lobsters from macrolgae/sanddominated sites, as shown by the mixing model. The proportion of seagrass in the gut contents of lobsters from macroalgae/sand-dominated sites was also higher than the maximum value (99th percentile) predicted by the mixing model (Fig. 3a).

Using the a posteriori groups of mobile invertebrates and sessile filter feeders, the model indicated that, for lobsters from both habitats, mobile invertebrates were necessary to balance the model, with minimum feasible solutions of 16 and $8 \%$ for seagrass- and macroalgae/sand-dominated sites, respectively (Fig. 3b).The maximum feasible solutions for mobile invertebrates and sessile filter feeders were higher for seagrass-dominated habitat (86 and $68 \%$, respectively) than for the macroalgae/sanddominated habitat (both $48 \%$ ). The contribution to total gut content values fell within the range indicated by the mixing model for the mobile invertebrate and sessile filter feeders groups, although the inter-habitat trends were not closely mirrored by the 2 analyses.

Grouping all animal food sources into one animal group revealed that the inclusion of a high proportion of animal sources was necessary to balance the model. For lobsters collected from both seagrass- and macroalgae/sand-dominated sites, an inclusion of at least $44 \%$ animal prey was necessary to balance the model, with up to $98 \%$ in seagrass habitat and $78 \%$ in macroalgae and sand habitat. The proportion of animal prey in the gut contents was lower than that indicated by the model results; for lobster from seagrass-dominated sites this value was below the minimum (1st percentile) feasible solution provided by the mixing model (44\%).

\section{DISCUSSION}

\section{Factors affecting lobster gut contents and isotope signatures}

This study shows that the composition of benthic habitat on a landscape scale (i.e. $10 \mathrm{~s}$ to $100 \mathrm{~s}$ of metres) affects the gut contents and isotope signatures of Panulirus cygnus from shallow coastal waters. Specifically, both the gut contents and muscle tissue $\delta^{13} \mathrm{C}$ and $\delta^{15} \mathrm{~N}$ values of lobsters inhabiting patch reefs surrounded predominantly by meadows of seagrasses (Amphibolis spp. and Posidonia spp.) were different to those of lobsters from patch reefs surrounded by a higher proportion of macroalgaedominated pavement and sand. Although gut contents showed considerable variation among taxa in the diet of lobsters from sites dominated by Amphibolis spp., Posidonia spp., or macroalgae/sand, the overall diet of lobsters from the 2 seagrass habitats was similar. This suggests that the major habitatrelated differences in diet for $P$. cygnus in shallow coastal waters are between macroalgae/sand-dominated landscapes (typically in deeper, more exposed waters) and seagrass-dominated landscapes (typically in shallower and more protected waters; CALM 2005).

A likely mechanism explaining the differences in lobster diet between seagrass- and macroalgae/ sand-dominated landscapes is that the relative differences in the proportion of various habitats is influencing the relative abundance of prey items that lobsters are exposed to whilst foraging. Panulirus cygnus exhibits nocturnal movements over patches of sand, seagrass and macroalgae on a scale of $100 \mathrm{~s}$ of metres around patch-reefs (Jernakoff 1987, MacArthur et al. 2008), and underwater observations confirm that they forage over all of these habitats (Edgar 1990a, Jernakoff 1987). Thus, variation in the proportion of different habitats within the landscape could be expected to influence diet. Variation in the volume of gastropods consumed illustrates this point; gastropods were consumed in greater volumes by lobsters from seagrass-dominated sites and are generally more abundant in seagrass meadows than on patch reefs in the study region (L.D.M. pers. obs.). This hypothesis is supported by Edgar (1990a), who found that between-site differences in the volume of gastropods in $P$. cygnus diet were related to the abundance of gastropods in nearby seagrass meadows. Similarly, diet of the congeneric Caribbean spiny lobster $P$. argus reflects the abundance of small, slow-moving invertebrates in the patches of habitat surrounding coral patch reefs (Cox et al. 1997, Briones-Fourzan et al. 2003).

Neither sex nor size explained a significant level of variation in the diet of Panulirus cygnus. The absence of dietary difference between sexes is supported by a previous study on this species which has revealed that foraging movements are similar between male and female P. cygnus (Jernakoff 1987). 
Edgar (1990a) found that there were significant dietary differences in the proportions of prey ingested by different ontogenetic stages of $P$. cygnus. The lack of size-related dietary variation in the present study may in part be indicative of the larger sizes sampled (36 to $98 \mathrm{~mm} \mathrm{CL}$ ), in comparison with that of Edgar (1990a) (25 to $90 \mathrm{~mm} \mathrm{CL).}$

\section{Diet and nutrition of lobsters}

Gut contents revealed numerous taxa consumed by Panulirus cygnus from shallow coastal waters, including molluscs, crustaceans, polychaetes, echinoderms, ascidians, sponges, seagrass, coralline and non-coralline algae. This supports earlier classification of P. cygnus as opportunistic foragers (Joll \& Phillips 1984, Edgar 1990a), as is the case for other palinurid lobsters (i.e. Jasus edwardsii, Guest et al. 2009; Panulirus argus, Briones-Fourzan et al. 2003; Palinurus elephas, Goni et al. 2001).

Articulated coralline algae were important to the nutrition of Panulirus cygnus, particularly from macroalgae/sand-dominated sites. The model predicted a minimum contribution of $22 \%$ to the nutrition of lobsters from these sites. The results indicate that coralline algae can contribute $\mathrm{N}$ and $\mathrm{C}$ for muscle maintenance in additional to a likely role in providing Ca for shell maintenance, as found by Joll \& Crossland (1983). The ubiquity of articulated coralline algae in coastal ecosystems along the west coast of Australia (Borowitzka et al. 1990, Huisman 2000, Lavery \& Vanderklift 2002), as an epiphyte on seagrasses, and as a component of reef biota, suggests that it is a universally important food source for $P$. cygnus across its distribution. Previous research, however, suggests that the growth rate of lobster feeding on predominantly coralline algae is slower than lobsters feeding predominantly on animal prey (Edgar 1990a, Joll \& Phillips 1984). This may indicate a slower growth rate of lobsters from macroalgae/ sand-dominated landscapes compared with seagrass-dominated landscapes, as stable isotope mixing model analysis indicated a more important role of articulated coralline algae for lobsters from the former habitat.

Mixing model results indicated that animal prey was more important to the nutrition of lobsters than plant food sources, contributing $44-98 \%$ to nutrition. For lobsters from seagrass-dominated sites, both the gut content and mixing model results suggest that mobile invertebrate prey are more important to diet and nutrition than sessile filter feeders (comprising mainly sponges and ascidians). For lobsters from macroalgae/sand-dominated sites, both gut contents and mixing model results suggest that mobile invertebrate prey and sessile filter feeders contribute roughly the same amount to diet and nutrition. Indeed, gut content analysis showed that sessile filter feeders comprised roughly a quarter of the gut contents of lobsters from macroalgae/ sand-dominated sites, over twice the contribution made to lobsters from seagrass-dominated sites, and much higher than indicated in past dietary studies of Panulirus cygnus. Because the minimum feasible contribution of sessile filter feeders to the nutrition of $P$. cygnus from both habitat categories took a value of $0 \%$, the importance of this food group to $P$. cygnus could not be definitively assessed. However, a previous study of the confamilial southern rock lobster Jasus edwardsii, using stable isotopes, has identified ascidians to be an important source of nutrition at some sites (Guest et al. 2009). The high proportion of this food in the guts of $P$. cygnus indicates that it may similarly be important to P. cygnus nutrition.

Mixing model and gut content results were unable to reveal whether cannibalism occurs in the habitats studied. Although mixing model data showed that lobster flesh potentially contributes to lobster nutrition, gut content data revealed only lobster shell, with no obvious signs of attached flesh. This likely represents fragments of discarded moults (exuviae), which lobsters, including Panulirus cygnus, are known to consume (Joll \& Phillips 1984, Edgar 1990a). It may also be possible, however, that lobsters scavenge flesh off the shells of conspecifics, as has been observed in captive conditions (Chittleborough 1975), without this flesh being readily identified in the guts. The high natural mortality of juvenile lobsters in the region ( $\geq 50 \%$ between age classes; Phillips et al. 2003) suggests that lobster carrion may be occasionally available. The role of exuviae to lobster nutrition was not explored here as the isotopic signature of shell was not tested in the model; however, moults may potentially be another source of energy for lobster as well as a source of Ca. There was a high degree of variation in the volume of shell ingested by individuals and thus no significant differences between habitats were observed.

The possibility of bait contributing significantly to lobster nutrition was raised by the mixing model results. Although bait was only readily available from macroalgae/sand-dominated sites in the study area (as these were the only sites exposed to lobster 
potting), mixing model results suggest that bait may be an important component of lobster nutrition, potentially comprising up to $\sim 30 \%$ of diet. This study supports the findings of Waddington et al. (2008) for Panulirus cygnus in deeper offshore waters, and those for the clawed lobster Homarus americanus from Saila et al. (2002), who found that bait may be subsidising lobster production. Certainly, bait is added in large quantities to lobster habitats along the west coast of Australia; across the fishery, an average of $1.3 \mathrm{~kg}$ of bait added for every $1 \mathrm{~kg}$ of lobster removed has been recorded (Fletcher et al. 2005). Consistent with the results presented here, mass balance modelling by Waddington \& Meeuwig (2009) suggests that during certain months, bait taken from pots and discarded by fisherman could contribute up to $35 \%$ of P. cygnus growth. These results parallel terrestrial studies where the diet of generalist consumers are often subsidised by anthropogenic food sources (e.g. foxes; Farias \& Kittlein 2008).

Results from the present study indicate that animal prey is more important to lobster nutrition than indicated by gut contents, and plant food sources are less important to nutrition than indicated by gut content. A similar discrepancy in the proportion of dietary plant (leaf detritus) and animal (invertebrate) prey in gut contents and tissue stable isotopes has been identified for freshwater crayfish (Parkyn et al. 2001). One potential reason for the observed discrepancy between gut content and stable isotope results may be the preferential routing of animal-derived nutrients into muscle tissue (see Gannes et al. 1997). Although the mixing model accounted for differences in C:N between plant and animal prey, as well as for the presence of refractory compounds in plants, it assumed equal assimilation of all food sources after making these adjustments. It is possible that nutrients derived from animal compounds are preferentially routed into Panulirus cygnus muscle tissue, thus explaining the higher proportion of animal prey in diet suggested by the stable isotope data.

Errors involved in analysing gut contents or different gut evacuation rates of animals and plant
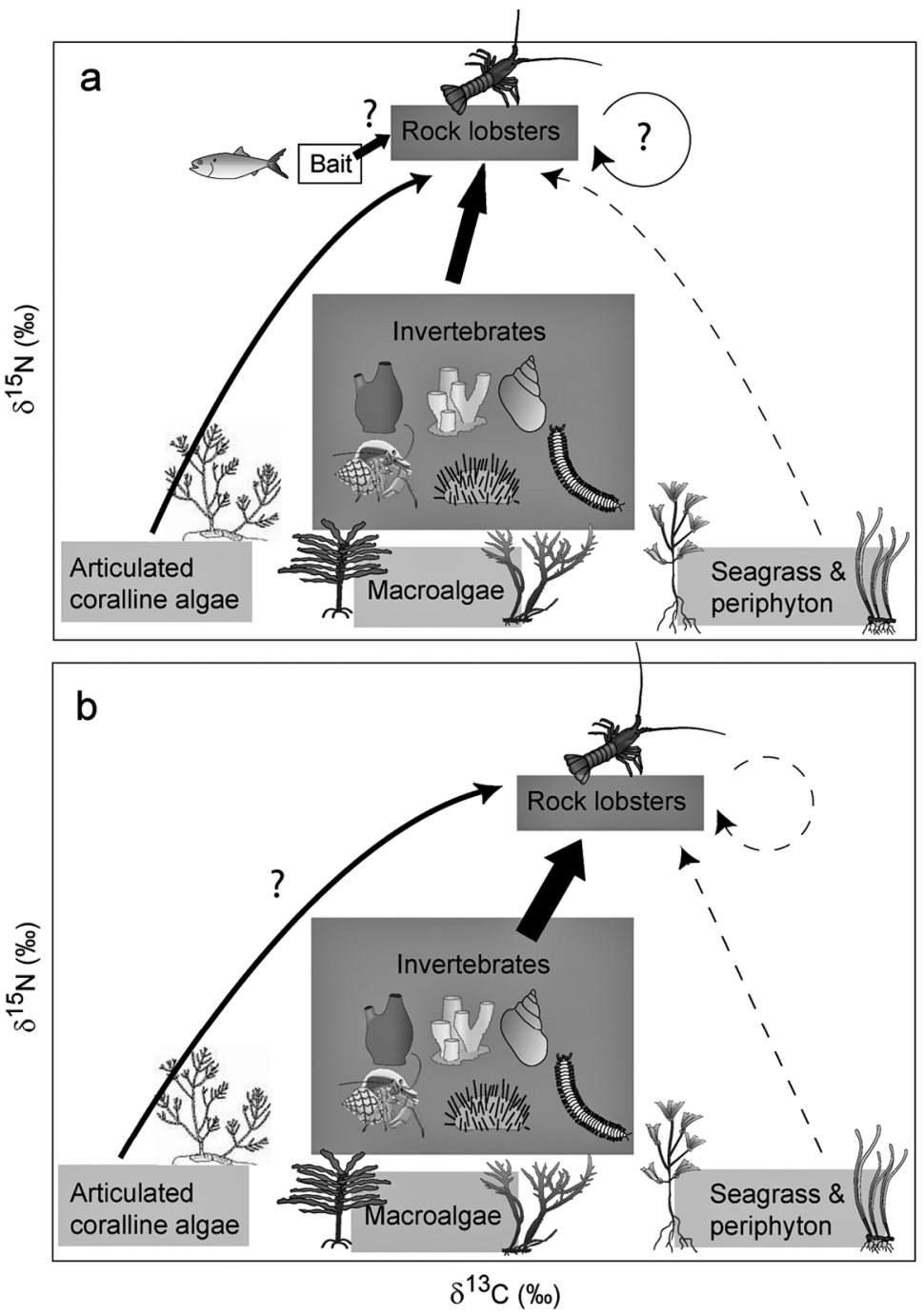

Fig. 4. Conceptual diagram indicating trophic linkages of Panulirus cygnus in (a) macroalgae/sand habitat and (b) seagrass habitat, as determined from mixing model analysis. Solid arrows indicate important sources of nutrition for lobsters. Solid lines with '?' indicate potentially important sources of nutrition. Thicker lines indicate greater contribution. Dashed lines indicate unimportant sources of nutrition

material are unlikely to entirely explain the discrepancies between the 2 approaches. Although animal prey was more difficult to identify in the foregut than plant material, the proportion of unidentified material was not large $(<8 \%)$, suggesting that even if this material comprised animals, the influence on the results would not be great. Further, the evacuation of plant material (articulated coralline algae) from the foregut of Panulirus cygnus is quicker than the evacuation of some invertebrate prey (crabs and pilchards, Waddington 2008), suggesting that gut content analysis might overestimate not underestimate the proportion of animal prey. 


\section{Trophic linkages between lobsters, invertebrate prey and primary production}

This study indicates a direct link between primary production and lobsters through the consumption of articulated coralline red algae, particularly in macroalgae/sand-dominated habitat (Fig. 4). Other omnivorous species inhabiting reef and seagrass beds also consume articulated coralline red algae (e.g. the teleost Odax acroptilus; MacArthur \& Hyndes 2007). In comparison, seagrass appears to play a negligible trophic role for Panulirus cygnus, both as a directly consumed source of nutrition and probably as a food source for invertebrate prey (Smit et al. 2005, 2006). Seagrass meadows of Amphibolis spp. and Posidonia spp. are, however, important habitats for invertebrate species consumed by lobsters (Edgar 1990b), and are used as foraging habitat by nocturnally active lobsters (Jernakoff 1987, MacArthur et al. 2008).

This study identified a strong trophic linkage between lobsters and invertebrate prey (Fig. 4). Based on a generalised average consumer-diet $\delta^{13} \mathrm{C}$ enrichment of 0-1\% (DeNiro \& Epstein 1978, McConnaughey \& McRoy 1979), the similar $\delta^{13} \mathrm{C}$ values of invertebrates compared with macroalgae suggests that macroalgae are likely to be an important source of primary production for invertebrates and, ultimately, Panulirus cygnus in shallow coastal waters. Other studies have found macroalgae to be a similarly important source of $\mathrm{C}$ for reef and seagrass invertebrates (Kitting et al. 1984, Cebrian \& Duarte 2001, Smit et al. 2005, 2006), including lobsters (Stephenson et al. 1986, Behringer \& Butler 2006, Brown 2006).

Acknowledgements. This paper has been subjected to the US Environmental Protection Agency's peer and administrative review and approved for publication. Mention of trade names or commercial products does not constitute endorsement or recommendation for use. The authors gratefully acknowledge R. Babcock, K. \& B. Cook, J. Eyres, E. Gates, S. Harrison, R. Kenna, M. Nyegaard, A. Tennyson and K. Waddington for assistance in the field and J. Tranter for the stable isotope analysis. The authors acknowledge the contributions of 2 anonymous reviewers, which improved the manuscript. Financial support for this study was provided by Edith Cowan University and the Strategic Research Fund for the Marine Environment.

\section{LITERATURE CITED}

Acosta CA (1999) Benthic dispersal of Caribbean spiny lobsters among insular habitats: implications for the conservation of exploited marine species. Conserv Biol 13: 603-612

> Akaike H (1974) A new look at statistical model identification. IEEE Trans Automat Contr 19:716-723

Behringer DC, Butler MJ (2006) Stable isotope analysis of production and trophic relationships in a tropical marine hard-bottom community. Oecologia 148:334-341

- Borowitzka MA, Lethbridge RC, Charlton L (1990) Species richness, spatial distribution and colonisation pattern of algal and invertebrate epiphytes on the seagrass Amphibolis griffithii. Mar Ecol Prog Ser 64:281-291

Boutton TW (1991) Stable isotope ratios of natural materials: I. Sample preparation and mass spectrometric analysis. In: Coleman DC, Fry B (eds) Carbon isotope techniques. Academic Press, San Diego, CA, p. 155-171

Briones-Fourzan $P$, Castaneda-Fernandez de Lara V, Lozano-Alvarez E, Estrada-Olivio J (2003) Feeding ecology of the three juvenile phases of the spiny lobster Panulirus argus in a tropical reef lagoon. Mar Biol 142:855865

Brown AC (2006) Effect of natural and laboratory diet on O: $\mathrm{N}$ ratio in juvenile lobsters (Homarus americanus). Comp Biochem Physiol A 144:93-97

CALM (Conservation and Land Management) (2005) Jurien Bay Marine Park Management Plan 2005-2015. Department of Conservation and Land Management, Perth

Catacutan MR, Eusebio PS, Teshima S (2003) Apparent digestibility of selected feedstuffs by mud crab, Scylla serrata. Aquaculture 216:253-261

Cebrian J, Duarte CM (1998) Patterns in leaf herbivory on seagrasses. Aquat Bot 60:67-82

- Cebrian J, Duarte CM (2001) Detrital stocks and dynamics of the seagrass Posidonia oceanica (L.) Delile in the Spanish Mediterranean. Aquat Bot 70:295-309

Chittleborough RG (1975) Environmental factors affecting growth and survival of juvenile western rock lobsters Panulirus longipes (Milne-Edwards). Aust J Mar Freshw Res 26:177-196

Cobb JS (1981) Behaviour of the Western Australian spiny lobster, Panulirus cygnus George, in the field and laboratory. Aust J Mar Freshw Res 32:399-409

> Cox C, Hunt JH, Lyons WG, Davis GE (1997) Nocturnal foraging of the Caribbean spiny lobster (Panulirus argus) on offshore reefs of Florida, USA. Mar Freshw Res 48: 671-679

> DeNiro MJ, Epstein S (1978) Influence of diet on the distribution of carbon isotopes in animals. Geochim Cosmochim Acta 42:495-506

Edgar GJ (1990a) Predator-prey interactions in seagrass beds. I. The influence of macrofaunal abundance and size-structure on the diet and growth of the western rock lobster Panulirus cygnus George. J Exp Mar Biol Ecol 139:1-22

Edgar GJ (1990b) Predator-prey interactions in seagrass beds. III. Impacts of the western rock lobster Panulirus cygnus George on epifaunal gastropod populations. J Exp Mar Biol Ecol 139:33-42

> Farias AA, Kittlein MJ (2008) Small-scale spatial variability in the diet of pampas foxes (Pseudalopex gymocercus) and human-induced changes in prey base. Ecol Res 23: 543-550

Fletcher WJ, Chubb C, McCrea J, Caputi N, Webster F, Gould R, Bray T (2005) ESD Report Series No. 4. Western rock lobster fishery. Department of Fisheries, Perth, Western Australia

- Gannes LZ, O' Brien DM, Martinez del Rio C (1997) Stable isotopes in animal ecology: Assumptions, caveats, and a call for more laboratory experiments. Ecology 78: 1271-1276

Goni R, Renones O, Quetglas A (2001) Dynamics of a pro- 
tected western Mediterranean population of the European spiny lobster Panulirus elephas (Fabricius, 1787) assessed by trap surveys. Mar Freshw Res 52:1577-1587

Gonzalez-Pena MDC, Anderson AJ, Smith DM, Moreira GS (2002) Effect of dietary cellulose on digestion in the prawn Macrobrachium rosenbergii. Aquaculture 211: 291-303

> Grober-Dunsmore R, Frazer TK, Lindberg WJ, Beets J (2007) Reef fish and habitat relationships in a Caribbean seascape: the importance of reef context. Coral Reefs 26: 201-216

Guest MA, Frusher SD, Nichols PD, Johnson CR, Wheatley KE (2009) Trophic effects of fishing southern rock lobster Jasus edwardsii shown by combined fatty acid and stable isotope analyses. Mar Ecol Prog Ser 388:169-184

> Hobson KA (1999) Tracing origins and migration of wildlife using stable isotopes: a review. Oecologia 120:314-326

Huisman JM (2000) Marine plants of Australia. University of Western Australia Press, Nedlands

> Irlandi EA, Crawford MK (1997) Habitat linkages: the effect of intertidal saltmarshes and adjacent subtidal habitats on abundance, movement, and growth of an estuarine fish. Oecologia 110:222-230

> Jernakoff P (1987) Foraging patterns of juvenile western rock lobsters Panulirus cygnus George. J Exp Mar Biol Ecol 113:125-144

> Jernakoff P, Phillips BF, Fitzpatrick JJ (1993) The diet of post-puerulus western rock lobster, Panulirus cygnus George, at Seven Mile Beach, Western Australia. Aust J Mar Freshw Res 44:649-655

> Johnston DJ (2003) Ontogenetic changes in digestive enzyme activity of the spiny lobster, Jasus edwardsii (Decapoda; Palinuridae). Mar Biol 143:1071-1082

> Joll LM, Crossland CJ (1983) Calcium uptake by juvenile western rock lobster, Panulirus cygnus George, from dietary coralline algae. J Exp Mar Biol Ecol 66:69-80

> Joll LM, Phillips BF (1984) Natural diet and growth of juvenile rock lobsters Panulirus cygnus George. J Exp Mar Biol Ecol 75:145-169

> Jones PL, De Silva SS (1997) Apparent nutrient digestibility of formulated diets by the Australian freshwater crayfish Cherax destructor Clark (Decapoda, Parastacidae). Aquacult Res 28:881-891

Kitting CL, Fry B, Morgan MD (1984) Detection of inconspicuous epiphytic algae supporting food webs in seagrass beds. Oecologia 62:145-149

Koch PL, Phillips DL (2002) Incorporating concentration dependence in stable isotope mixing models: a reply to Robbins, Hilderbrand and Farley. Oecologia 133:14-18

Langlois TJ, Anderson MJ, Babcock RC (2005) Reef-associated predators influence adjacent soft-sediment communities. Ecology 86:1508-1519

> Lavery PS, Vanderklift MA (2002) A comparison of spatial and temporal patterns in epiphytic macroalgal assemblages of the seagrasses Amphibolis griffithii and Posidonia coriacea. Mar Ecol Prog Ser 236:99-112

MacArthur LD, Hyndes GA (2007) Varying foraging strategies of Labridae in seagrass habitats: Herbivory in temperate seagrass meadows? J Exp Mar Biol Ecol 340: 247-258

> MacArthur LD, Hyndes GA, Babcock RC, Vanderklift MA (2008) Nocturnally active western rock lobsters Panulirus cygnus forage close to shallow coastal reefs. Aquat Biol 4:201-210

Marsham S, Scott GW, Tobin ML (2007) Comparison of nutritive chemistry of a range of temperate seaweeds. Food Chem 100:1331-1336

McAfee ST, Morgan SG (1996) Resource use by five sympatric parrotfishes in the San Blas Archipelago, Panama. Mar Biol 125:427-437

McArdle BH, Anderson MJ (2001) Fitting multivariate models to community data: a comment on distance-based redundancy analysis. Ecology 82:290-297

McConnaughey T, McRoy CP (1979) Food-web structure and the fractionation of carbon isotopes in the Bering Sea. Mar Biol 53:257-262

McDermid KJ, Stuercke B, Haleakala OJ (2005) Total dietary fiber content in Hawaiian marine algae. Bot Mar 48:437-440

> Meyer CG, Holland KN, Wetherbee BM, Lowe CG (2000) Movement patterns, habitat utilization, home range size and site fidelity of whitesaddle goatfish, Parupeneus porphyreus, in a marine reserve. Environ Biol Fishes 59: 235-242

Micheli F, Peterson CH (1999) Estuarine vegetated habitats as corridors for predator movements. Conserv Biol 13: 869-881

> Minagawa M, Wada E (1984) Stepwise enrichment of $\delta^{15} \mathrm{~N}$ along food chains: further evidence and the relationship between $\delta^{15} \mathrm{~N}$ and animal age. Geochim Cosmochim Acta 48:1135-1140

> Newsome SD, Phillips DL, Culleton BJ, Guilderson TP, Koch PL (2004) Dietary reconstruction of an early to middle Holocene human population from the central California coast: insights from advanced stable isotope mixing models. J Archaeol Sci 31:1101-1115

Nichols PD, Klumpp DW, Johns RB (1982) Lipid components of the seagrasses Posidonia australis and Heterozostera tasmanica as indicators of carbon source. Phytochemistry 21:1613-1621

> Parkyn SM, Collier KJ, Hicks BJ (2001) New Zealand stream crayfish: Functional omnivores but trophic predators? Freshw Biol 46:641-652

Parrish JD (1989) Fish communities of interacting shallowwater habitats in tropical oceanic regions. Mar Ecol Prog Ser 58:143-160

Phillips DL, Gregg JW (2003) Source partitioning using stable isotopes: coping with too many sources. Oecologia 136:261-269

Phillips BF, Melville-Smith R, Cheng YW (2003) Estimating the effects of removing Panulirus cygnus pueruli on the fishery stock. Fish Res 65:89-101

Phillips DL, Newsome SD, Gregg JW (2005) Combining sources in stable isotope mixing models: alternative methods. Oecologia 144:520-527

Polis GA, Anderson WB, Holt RD (1997) Toward an integration of landscape and food web ecology: the dynamics of spatially subsidized food webs. Annu Rev Ecol Syst 28: 289-316

> Posey MH, Ambrose WG (1994) Effects of proximity to an offshore hard-bottom reef on infaunal abundances. Mar Biol 118:745-753

> Randall JE (1965) Grazing effect on seagrasses by herbivorous reef fishes in the West Indies. Ecology 46:255-260

> Rilov G, Schiel DR (2006) Trophic linkages across seascapes: subtidal predators limit effective mussel recruitment in rocky intertidal communities. Mar Ecol Prog Ser 327:83-93

Robbins CT (1993) Wildlife feeding and nutrition. Academic Press, San Diego, CA

Saila SB, Nixon SW, Oviatt CA (2002) Does lobster trap bait 
influence the Maine inshore trap fishery? N Am J Fish Manage 22:602-605

Smit AJ, Brearley A, Hyndes GA, Lavery PS, Walker DI (2005) Carbon and nitrogen stable isotope analysis of an Amphibolis griffithii seagrass bed. Estuar Coast Shelf Sci 65:545-556

Smit AJ, Brearley A, Hyndes GA, Lavery PS, Walker DI (2006) $\delta^{15} \mathrm{~N}$ and $\delta^{13} \mathrm{C}$ analysis of a Posidonia sinuosa seagrass bed. Aquat Bot 84:277-282

Stephenson RL, Tan FC, Mann KH (1986) Use of stable carbon isotope ratios to compare plant material and potential consumers in a seagrass bed and a kelp bed in Nova Scotia, Canada. Mar Ecol Prog Ser 30:1-7

Tanner JE (2006) Landscape ecology of interactions between seagrass and mobile epifauna: The matrix matters. Estuar Coast Shelf Sci 68:404-412

Torbatinejad NM, Annison G, Rutherfurd-Markwick K, Sabine JR (2007) Structural constituents of the seagrass Posidonia australis. J Agric Food Chem 55:4021-4026

> Valentine JF, Heck KL Jr, Blackmon D, Goecker ME and

Editorial responsibility: James McClintock,

Birmingham, Alabama, USA others (2007) Food web interactions among seagrasscoral reef boundaries: effects of piscivore reductions on cross-habitat energy exchange. Mar Ecol Prog Ser 333: $37-50$

Waddington K (2008) Variation in evacuation rates of different foods skew estimates of diet in the western rock lobster Panulirus cygnus. Mar Freshw Res 59:347-350

Waddington K, MacArthur L (2008) Diet quality and muscle tissue location influence consumer-diet discrimination in captive-reared rock lobsters (Panulirus cygnus). Mar Biol 154:569-576

Waddington K, Meeuwig J (2009) Contribution of bait to lobster production in an oligotrophic marine ecosystem as determined using a mass balance model. Fish Res 99:1-6

Waddington KI, Bellchambers LM, Vanderklift MA, Walker DI (2008) Western rock lobster (Panulirus cygnus) in Western Australian deep coastal ecosystems (35-60 m) are more carnivorous than those in shallow coastal ecosystems. Estuar Coast Shelf Sci 79:114-120

Submitted: July 6, 2010; Accepted: June 10, 2011

Proofs received from author(s): August 22, 2011 